\title{
3. 血管作㗢物䆝の動脈硬化血管における反応性
}

\author{
横山光 宏 ${ }^{1)}$ 粟野孝次郎 ${ }^{1)}$ 秋田穂 束 ${ }^{1)}$ \\ 福 崎恒 ${ }^{1)}$ 渡 辺嘉 雄 ${ }^{2)}$ \\ 神戸大学医学部 第一内科 ${ }^{2}$, 同 動物実験施設 2
}

Altered Responsiveness of Atherosclerotic Arteries to

Vasoactive Substances

Mitsuhiro YOKOYAMA, ${ }^{1)}$ Kojiro AWANO, ${ }^{1)}$ Hozuka AKITA, ${ }^{1)}$

Hisashi FUKUZAKI ${ }^{1)}$ and Yoshio WATANABE ${ }^{2)}$

First Department of Medicine ${ }^{1)}$ and Institute for Experimental Animals, $\left.{ }^{2}\right)$

Kobe University School of Medicine, Kobe

\begin{abstract}
Summary
The interactions between platelets and vascular walls have special significance for atherosclerotic heart disease. The aims of this study were to determine whether atherosclerosis is associated with altered vascular reactivity to aggregating platelets and to elucidate the responsible underlying mechanisms. Isolated helical strips of aortae and coronary arteries from age-matched control and Watanabe Heritable Hyperlipidemic rabbits (WHHL rabbits) (average age $=10$ months for aortic study and 22 months for coronary study) were mounted for isometric tension recording in oxygenated buffer. All the segments of aortae and coronary arteries from WHHL rabbits showed atherosclerotic lesions macroscopically. Cumulative additions of suspended platelets $\left(10^{4}-3 \times 10^{6} /\right.$ $\mu$ l) activated with thrombin into the organ bath resulted in platelet count-related aortic contractions. The maximum serotonin (5HT) and thromboxane (TX) $\mathrm{B}_{2}$ concentration in the bath solution averaged $148 \mathrm{ng} / \mathrm{ml}$ and $24 \mathrm{ng} / \mathrm{ml}$. Contractile responses of atherosclerotic aortae to aggregating platelets were markedly augmented as compared to controls. An incubation of platelets with aspirin, which completely inhibited TX $\mathrm{A}_{2}$ synthesis without any alterations of $5 \mathrm{HT}$ release, did not attenuate hyperreactivity of atherosclerotic aortae compared to controls. Prior exposure to phentolamine or diphenhydramine also did not alter contractile responses to aggregating platelets. The treatment of aortic strips with methysergide inhibited responses to aggregating platelets in both atherosclerotic and control groups, indicating a serotonergic mechanism of its hyperreactivity. To further elucidate its responsible mechanism, contractile responses to exogenously administered 5HT, histamine and TX $\mathrm{A}_{2}$ were examined in aortic strips from control and WHHL rabbits. Responsiveness of atherosclerotic aortae to $5 \mathrm{HT}$ was significantly augmented compared to controls. There were no differences in the responses to histamine between two groups. Atherosclerotic aortae exhibited impaired responses to TX $\mathrm{A}_{2}$ prepared by incubation of $\mathrm{PG} \mathrm{H}_{2}$ with calf platelet microsomes or ST $\mathrm{A}_{2}$, a stable TX-like analogue, as compared to controls. These results also can help to explain the mechanisms responsible for hyperreactivity of atherosclerotic aortae to aggregating platelets.

In addition, atherosclerotic coronary arteries exhibited a markedly enhanced reactivity to aggregating platelets and 5HT.
\end{abstract}

\section{緒 耳}

冠動脈攣縮は異型狭心症を含む種々の虚血性心疾患 の病因として重視されているが，その発症機序はまだ
明らかでない.われわれは多くの臨床観察に基づき， 冠動脈橔縮の原因として最も重要なのは血管自体の 収縮反応の克進であって, この異常反応に動脈硬化の 


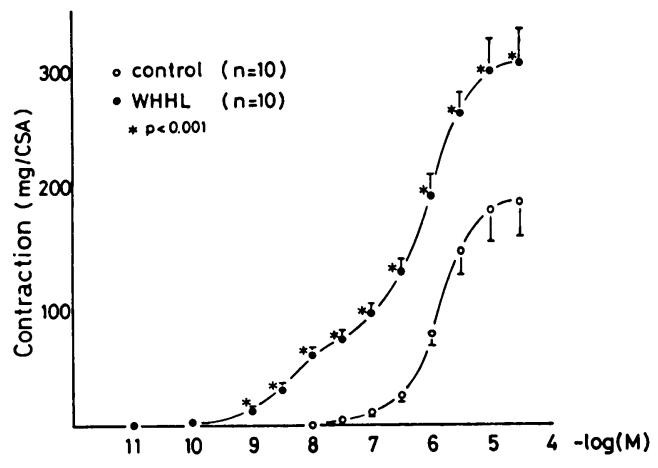

Fig. 1. Concentration-response relations for ergonovine in aortic strips. Vertical bars indicate SEM.

初期病变が関与しているとの仮説を立て, 種々の血管 作偪物質に対する動脈硬化血管の反応性を検討してき $た^{1,2)}$ ．実際，動脈硬化に陥った動脈の収縮性は低下 するすのと従前から考えられていたのに反し, 臨床

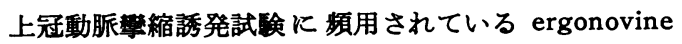
に対して動脈硬化大動脈と冠動脈は健常血管に比べて 著明な収縮反応の亢進を示し，この反応性の六進はセ ロトニン受容体機序によることを明らかにした（Fig. 1, Table $\left.{ }^{33}\right)$. 一方, 動脈硬化血管の phenylephrine や $\mathrm{KCl}$ に対する反応性には差異を認めなかった。 動脈硬化のモデル動物として, 最初高コレステロール 食飼育家鬼の大動脈を使用しだ)が，本モデルの最大 の欠点は易病性に個体によるばらつきが大きく，大動 脈における動脈硬化病変の分布と程度も一様でなく, しかも冠動脈病変の発生がきわめて稀である点にあ る. この意味で, WHHL rabbits は動脈硬化のモデ ル動物として最適と思われる

血小板は thrombin, collagen, ADP 等によって活 性化され，凝集反応が惹起され，強力な血管收縮物質 である serotonin や thromboxane (TX) $\mathrm{A}_{2}$ 等の生 理活性物質が放出される. 種々の虚血性心疾患患者に おいて血小板凝集反応の充進や血小板由来の血小板第 4 因子, $\beta$-thromboglobulin, TX $\mathrm{A}_{2}$ などの血中増加 が報告されている ${ }^{8,9)}$. 本研究では血小板活性化によっ て葆起される血管收粳機序を検討し，WHHL rabbits から摘出した大動脈と冠動脈の血小板活性化による収 樎効果の変化につき調べた。

\section{方 法}

WHHL rabbits と正常家鬼（いずれす月跲 10 カ月） を用いて央験を行った. Pentobarbital sodium（30 $\mathrm{mg} / \mathrm{kg}$ ，i.v.) 麻醉後，胸部大動脈と一部の実釦では 月龄 20 カ月の正常および WHHL rabbits の冠動脈を 摘出し,ラセン条片を作製した. 血管条片を $30 \mathrm{ml}$ の Krebs-Henseleit 溶液で満たした tissue bath 中に㣰 垂固定し，等尺性收樎力を測定した. Tissue bath 中 の栄養液は $95 \% \mathrm{O}_{2}$ と $5 \% \mathrm{CO}_{2}$ の混合ガスで通気さ れ, $\mathrm{pH}$ は 7.38, 温度は $37^{\circ} \mathrm{C}$ に保たれた。適当な preloadを与え， 2 時間にわたり stress relaxation を钼察し、まず $20 \mathrm{mM} \mathrm{KCl}$ に対する血管反応性を調 べたのち，実験に用いた。

正常家鬼の大腿動脈より ACD 採血し, Ardlie ら の方法に従って洗浄血小板浮遊液を作製後, 血小板数 を計測し， $10^{4} \sim 3 \times 10^{6} / \mu 1$ の血小板浮遊液を作製 乙 $た^{10)}$. 次に各淒度の洗浄血小板㐿遊液を $37^{\circ} \mathrm{C}, 5$ 分間 incubate したのち, $0.2 \mathrm{U} / \mathrm{ml}$ thrombin で 1 分間刺 激し, その $0.3 \mathrm{ml}$ を直接 $30 \mathrm{ml}$ の tissue bath 中 に順次加え，収縮反応を調べた．次に，5-hydroxytryptamine $(5 \mathrm{HT})$ と TX $\mathrm{A}_{2}$ の作用を分離する目的 $て$ て $5 \mathrm{HT}$ antagonists $と し て$ methysergide $(0.3$ $\mu \mathrm{M})$ で血管を処理したのち，thrombin 刺激血小板に 対する収縮反応を調べた，TX $\mathrm{A}_{2}$ 産生阻害の目的で， 血小板を aspirin $(0.5 \mathrm{mM})$ 処理したのち, thrombin 刺教し, tissue bath 中に加兄，収縮反応を調べた。 最後に, tissue bath 中の $5 \mathrm{HT}, \mathrm{TXB}_{2}$, norepinephrine (NE), histamine の濃度を調べた。

次に，外因性に投与した $5 \mathrm{HT}$ と TX $\mathrm{A}_{2}$ に対する濃 度一反応関係を WHHL rabbits と正常家鬼の大動脈 セン条片を用いて検討した. TX $\mathrm{A}_{2}$ は prostaglandin (PG) $\mathrm{H}_{2}\left(10^{-8} \sim 10^{-4} \mathrm{M}\right)$ と牛血小板 microsome (2 $\mathrm{mg}$ protein $/ \mathrm{ml}$ ) を反応させることにより作成するか, または安定な TX $\mathrm{A}_{2}$ analogue である ST $\mathrm{A}_{2}\left(10^{-12}\right.$ $\left.10^{-7} \mathrm{M}\right)$ を用いた。

\section{結 果}

本実験に用いた WHHL rabbits の大動脈と冠動脈 は全例肉眼的に弹状硬化病变を認めた。

正常家鬼の大動脈は thrombin 刺激血小板によって 血小板数に依存して収樎反応を生した（Fig.2）。 WHHL rabbits の大動脈では血小板活性化によって 生じる収樎反応は著しく充進していた，一方， $20 \mathrm{mM}$ $\mathrm{KCl}$ による収縮は両群の血管でまったく差異を認めな かった. 血小板添加後の tissue bath 中の $5 \mathrm{HT}$, $\mathrm{TX} \mathrm{B}_{2}$, histamine, NE 濃度はおのおの $148 \pm 11 \mathrm{ng} /$ $\mathrm{ml}, 24 \pm 2 \mathrm{ng} / \mathrm{ml}, 16 \pm 2 \mu \mathrm{g} / \mathrm{dl}$, 测定閥値以下であっ た. Aspirin 前処理血小板に対しても動脈硬化大動脈 


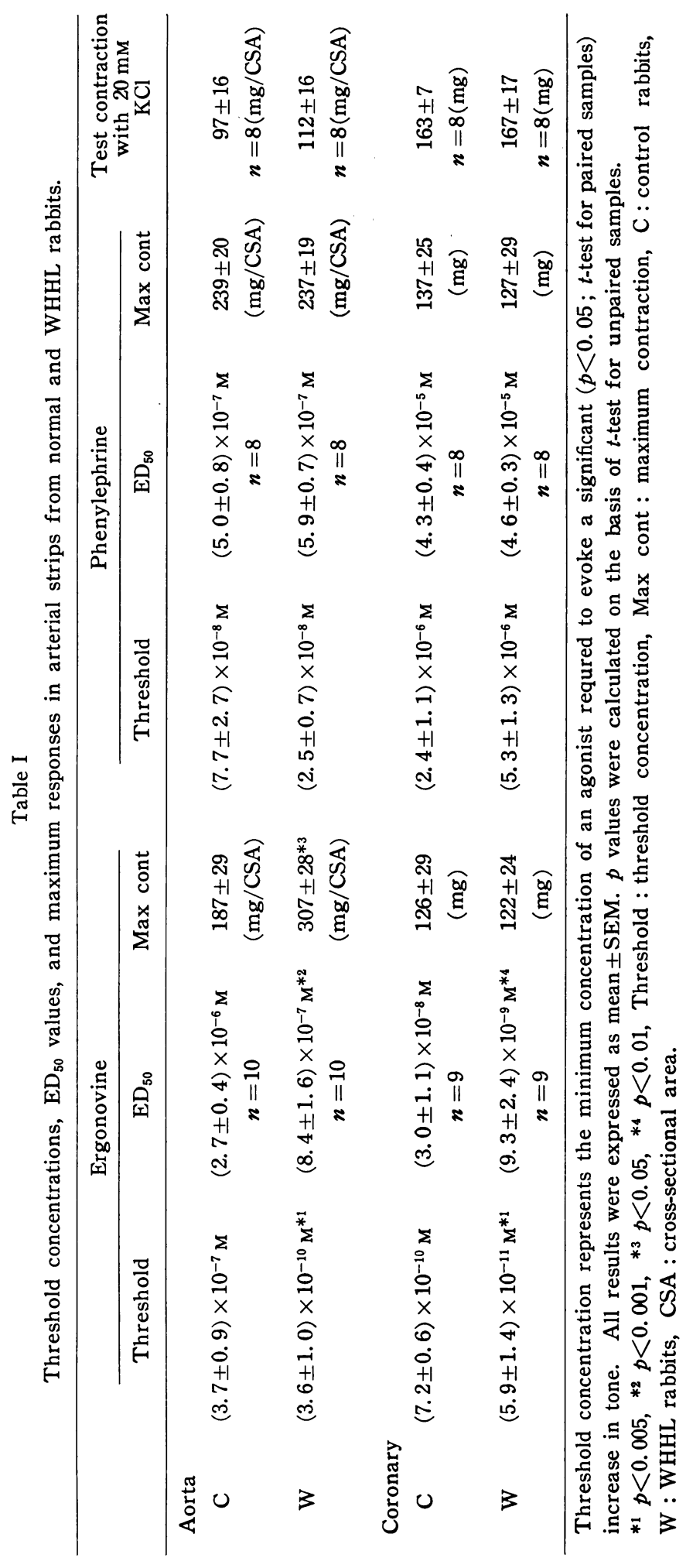



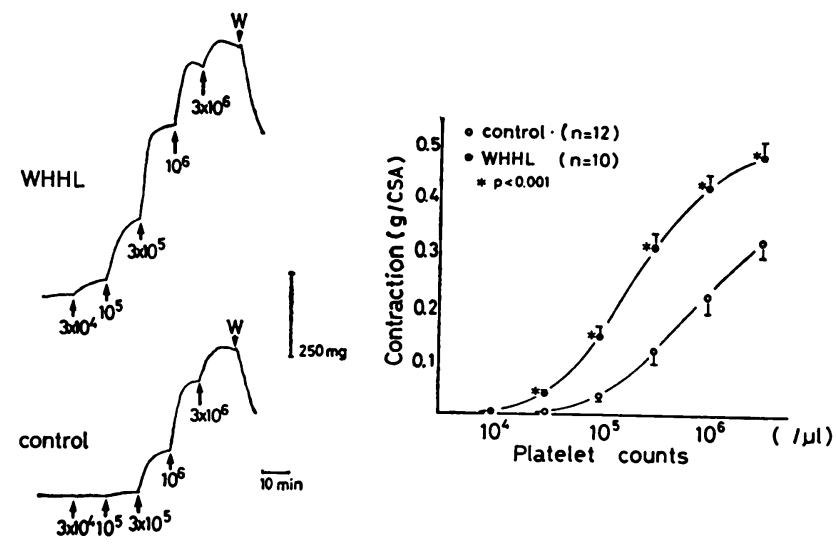

Fig.2. Contractile response of aortic strips to cumulative addition of $300 \mu \mathrm{l}$ platelet suspensions stimulated with thrombin $(0.2 \mathrm{U} / \mathrm{ml})$ to $30 \mathrm{ml}$ organ bath.

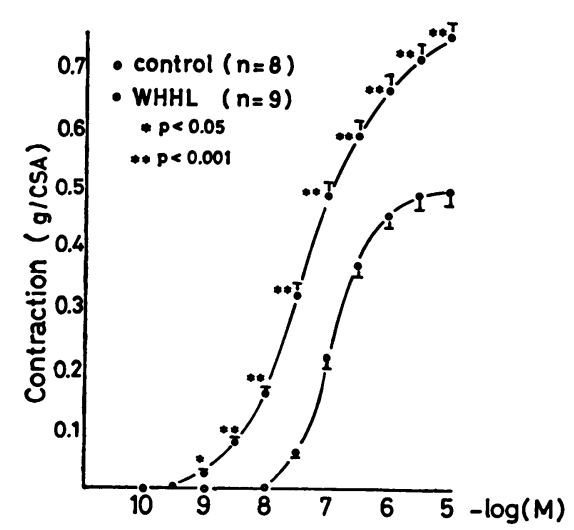

Fig.3. Concentration-response relations for serotonin in aortic strips.

は健常大動脈に比べて依然として収縮反応の著明なえ 進を示した. Tissue bath 中の $\mathrm{TX} \mathrm{B}_{2}$ 濃度は aspirin 処理によって $0.4 \pm 0.1 \mathrm{ng} / \mathrm{ml}$ に抑制されたが, $5 \mathrm{HT}$ 濃度は $148 \pm 15 \mathrm{ng} / \mathrm{ml}$ であった. 大動脈の methyser gide 前処理によって, 血小板活性化に伴う収縮反応 は著明に抑制されたが，WHHL rabbits の大動脈のほ らが健常大動脈に比べて抑制が大であった. 大動脈の phentolamine と diphenhydramine 前処理によって は，血小板活性化による収縮はまったく抑制されなか った.

次に WHHL rabbits の大動脈の $5 \mathrm{HT}$, histamine, TX $\mathrm{A}_{2}$ 自体の収縮効果を調べた. WHHL rabbits の 大動脈の $5 \mathrm{HT}$ に対する濃度一反応曲線は健常血管に 比べて左上方へ偏位し，動脈硬化血管の外因性に投与

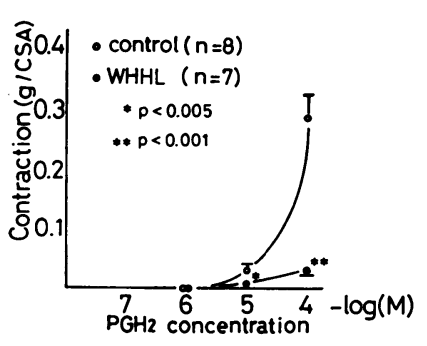

Fig.4. Contractile response of aortic strips to cumulative addition of $30 \mu \mathrm{l} \mathrm{PG} \mathrm{H}_{2}\left(10^{-7}-10^{-4}\right.$ M) incubated with calf platelet microsomes ( $2 \mathrm{mg}$ protein $/ \mathrm{ml}$ ) to $30 \mathrm{ml}$ organ bath.

した $5 \mathrm{HT}$ に対する収縮反応の六進が認められた (Fig.3). 動脈硬化血管の histamineに対する濃度-反 応曲線は健常血管と差異を認めなかった. $\mathrm{PG} \mathrm{H}_{2}$ と血 小板 microsome を反応させることにより生成した TX $\mathrm{A}_{2}$ に対する動脈硬化大動脈の濃度-反応曲線は健 常大動脈に比べて右下方へ偏位し, $T X A_{2}$ に対する 収縮反応の低下を認めた（Fig.4). また，ST A しても WHHL rabbits の大動脈は健常血管に比べて 収縮反応の低下を示した（Fig.5).

最後に WHHL rabbits の冠動脈は, 大動脈の成績 と同様に, 健常冠動脈に比べて thrombin 刺激血小板 と外因性に投与した 5 HTに対して著明な収縮反応の 充進を示した (Fig.6，7).

考案

遗伝性高脂血症家鬼は家族性高脂血症のモデル動物 として脂質代謝異常の解明にきわめて有用であること が広く知られているが，大動脈硬化症および冠動脈硬 


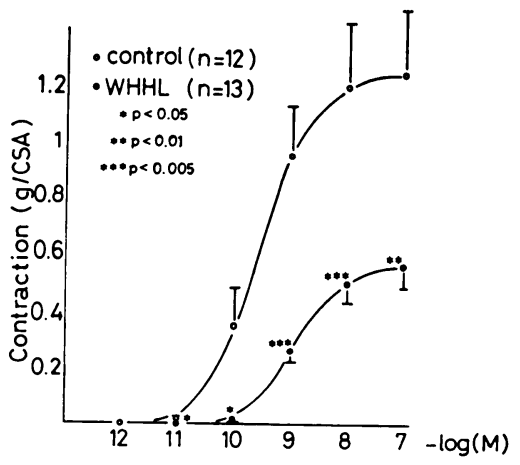

Fig.5. Concentration-response relations for ST $A_{2}$ in aortic strips.

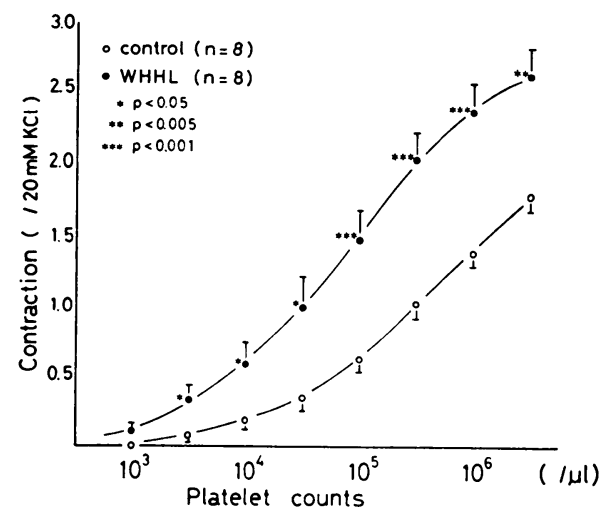

Fig.6. Contractile response of coronary arteries to cumulative addition of $300 \mu 1$ platelet suspensions stimulated with thrombin $(0.2 \mathrm{U} / \mathrm{ml})$ to $30 \mathrm{ml}$ organ bath.

化症の自然発症モデル動物としても重要である. WHHL rabbits の大動脈々冠動脈の张状硬化の組織 学的変化は七トの粥状硬化病变と類似している ${ }^{11)}$. 本 研究においてわれわれは WHHL rabbits を用いて张 状硬化病変を有する大動脈および冠動脈の収縮特性を 調べた。

血小板は $\mathrm{TX} \mathrm{A}_{2}$ や $5 \mathrm{HT}$ などの生理活性物質の産 生, 貯蔵の場であり, 血小板活性化汇伴ってこれらの 物質が放出される．今回血小板活性化によって惹起さ れる大動脈と冠動脈の収縮効果を各種受容体遮断薬と プロスタグランディン合成阻害薬を用いて調べた結 果, 血小板から放出される $5 \mathrm{HT}$ が主たる血管収縮物 質であり, TX $\mathrm{A}_{2}$ の関与は僅少であることが判明し た. 動脈硬化大動脈之冠動脈は血小板活性化によって 萀起される収縮反応の著明なえ進を示したが，その原

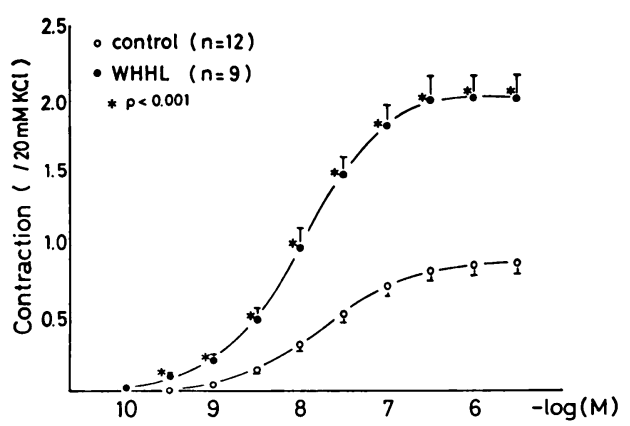

Fig.7. Concentration-response relations for $5 \mathrm{HT}$ in coronary arteries.

因として血小板から放出される $5 \mathrm{HT}$ に対する収縮反 応の元進によることが明らかとなった. 一方, 動脈硬 化血管は TX $\mathrm{A}_{2}$ に対しては収縮反応の低下を認めた。 このように動脈硬化血管が $5 \mathrm{HT}$ に対して選択的に収 縮反応の充進を示したことは，脂質蓄積によるイオン 透過性の亢進 ${ }^{12)}$ や血管平滑筋細胞の増殖では説明でき ず，血管細胞における受容体と刺激応答連関の機能異 常が示唆される.

文献

1) Yokoyama, M., Akita, H. and Fukuzaki, H. : Cardioangiology, 11, 250 (1982) (in Japanese)

2) Yokoyama, M., Akita, H. and Sakamoto, S. : J. Jpn. Coll. Angiol., 25, 177 (1985) (in Japanese)

3) Yokoyama, M., Akita, H., Mizutani, T., Fukuzaki, H. and Watanabe, Y. : Circ. Res., 53, 63 (1983)

4) Henry, P. and Yokoyama, M. : J. Clin. Invest., 66, 306 (1980)

5) Watana be, Y. : Atherosclerosis, 36, 261(1980)

6）渡辺嘉雄：疾患モデルハンドブック，川俣順一, 松下 宏編, 医歯薬出版, 東京, p. 93 (1979)

7) Watanabe, Y., Ito, T. and Shiomi, M. : Atherosclerosis, 56, 71 (1985)

8) Salky, N. and Dugdale, M. : Am. J. Cardiol., 32, 612 (1973)

9) Yokoyama, M., Kawashima, S., Sakamoto, S., Akita, H., Okada, T., Mizutani, T. and Fukuzaki, H. : Br. Heart J., 49, 20 (1983)

10) Ardlie, N.G., Packham, M.A. and Mustard, J.F. : Br. J. Haematol., 19, 7 (1970)

11) Buja, L.M., Kita, T., Goldstein, J.L., Watanabe, Y. and Brown, M.S. : Arteriosclerosis, 3, 87 (1983)

12) Yokoyama, M. and Henry, P.D. : Circ. Res., 45, 479 (1979) 